\title{
Relationships Between Minority Students Online Learning Experiences and Academic Performance
}

\author{
Alex Kumi Yeboah \\ University at Albany-SUNY \\ Patriann Smith \\ Texas Tech University, Lubbock Texas
}

\begin{abstract}
The study investigated the relationship between minority students' use of technology, social media, the number of online courses, program of study, satisfaction, and academic performance. Participants in the study were a diverse student body regarding age, gender, and educational level, and functioned at both undergraduate and graduate levels. Analysis of variance (ANOVA) and Chi-square tests were used to find the relationship between participants' online learning experiences and academic performance. Results showed that satisfaction and use of social media had no relationship with the academic performance of participants. However, a relationship existed between the use of technology, the number of courses in online, program of study, and academic performance. Categories that emerged from the open-ended questions were flexibility and time convenience, self-confidence, lack of support, self-regulated learning skills, and language and linguistic differences. The authors concluded that varying factors such as cultural, language, personal, and efficacy skills facilitated the academic performance of minority students in an online learning environment. This study reiterates the importance of establishing multicultural presence in an online course and suggests best pedagogical methods for teaching minority students in an online course.
\end{abstract}

Keywords: Minority students, satisfaction, social media, use of technology, academic performance, self-regulated learning, and self-confidence 


\section{Introduction}

The past two decades reflect a rapid increase in online learning in higher education. Online learning has taken the center stage as one of the best alternative means of instruction as compared to the traditional face-to-face classes. For instance, in 2012, the number of students who enrolled in at least one online course increased by over 570,000 to a new total of 6.7 million. In 2014, the proportion of higher education students in online education was at an alltime high of $33.5 \%$ (Allen \& Seaman, 2014). Online education has shifted to a mainstream form of delivery for the majority of higher education institutions. This is primarily due to the growing and aging undergraduate population, rising tuition costs that led to innovative alternatives, an evolving workforce seeking lifelong learning options, and academic leaders' strategic focus to develop online learning strategies (Allen \& Seaman, 2014). This phenomenon has made most colleges and universities adopt online courses as alternative offerings that are scalable, sustainable and personalized to improve academic and employment outcomes for learners (Babson Survey Report, 2014). Several studies (Brown \& Liedholm, 2002; Coates, Humphreys, Kane, \& Vachris, 2004; Rovai, Ponton, Wighting, \& Baker, 2007; Xu \& Jaggars, 2011; Xu \& Jaggars, 2013) indicated that students who choose online learning seem to have higher levels of academic ability and motivation in comparison to peers who select a fully face-to-face course.

Amidst the increasing growth of online education is the notion of technology as a major instructional path for university students who opt to take online or hybrid courses using available computers and information technologies (Allen \& Seaman, 2008). New generations of students in higher education expect instructors to integrate new technologies, such as online learning management systems and collaborative Internet technologies into traditional face-to-face class to enhance their learning experience. A recent study by EDUCAUSE (Hawkins \& Rudy, 2008) reported that the majority of U.S. students at baccalaureate degree-granting institutions own and use their computers. Online learning management systems (LMS) such as Blackboard, Desire to Learn (D2L), Angel, Canvas, or Sakai are universally applicable to universities, and wireless Internet access permeates most college classrooms (Green, 2007; Hawkins \& Rudy, 2008). Several studies indicated that online courses require students to assume greater responsibility for their learning. For example, a successful online student may need high levels of self-regulation, self-discipline, and metacognitive skills, which often falls under the broad rubric of self-directed learning (Azevedo, Cromley, \& Seibert, 2004; Corbeil, 2003; Guglielmino \& Guglielmino, 2002; Hannafin \& Land, 1997; Kearsley, 2002; Williams, 1996; Yen \& Liu, 2009).

Online learning provides students, the ability to self-monitor their understandings, reflects, control interactions about the concepts they learn in an online setting (Means, Toyama, Murphy, Bakia, \& Jones, 2009). As more students continue to pursue degrees through online learning, students' pre-existing cultural dispositions associated with their ethnicity or age can largely influence their learning actions and thoughts, which may be in conflict with the regular online learning practices and environments. Further, since the inception of online or blended learning courses in college programs, minority students have participated in either fully online course or blended learning to augment their academic endeavors. Some research studies (Adeoye \& Wentling, 2007; Hughes \& Bruce, 2006) contend that online courses ignore cultural and subcultural differences in learning behavior and fail to address the diversity of their learners. However, not much research has been done to investigate the relationship between minority students' online learning experiences and academic performance using a mixed-method 
approach. Therefore, the primary focus of this study is to investigate the relationship between minority students' satisfaction and experiences with online learning and their academic performance (As measured by their Grade Point Average). The study's findings on minority students' satisfaction in online learning participation and academic performance (As measured by Grade Point Average) will serve to better inform faculty, educational researchers, and policy makers on assessing how online learning courses relate to the cultural responsiveness, multicultural expectations, challenges, and achievement of minority students. In the following sections, we provide a literature review and a description of the study design and methods, followed by the study results, a discussion of the findings, implications, recommendations, and the conclusion.

\section{Literature Review}

Learning satisfaction in online learning is defined as student's perceptions about the course experience and the perceived value of the education received while attending the educational institution (Astin, 1993; Bollinger \& Martindale, 2004). Online course refers to a learning process in which at least $80 \%$ of the course content is delivered online. The course content is delivered via an online learning format (Babson Research Survey/Online Learning Consortium, 2014). Several researchers (Eom, Wen, \& Ashill, 2006; Sun, Tsai, Finger, Chen \& Yeh, 2008) agreed that user satisfaction in online learning is a critical measure of learning outcomes and factor into the success of online educational system implementation. Online learning satisfaction is comprised of two dimensions: perceived satisfaction with individual online courses, and an overall satisfaction with web-based distance education. Researchers in web-based education have suggested the need to create diverse online learning interactions for students, particularly for minority students with limited English and social limitations in online education (Ke \& Carr-Chellman, 2006).

\section{Online Learning Interaction and Satisfaction}

According to Thurmond (2003) interaction in online learning is the process where:

...the learner's engagement with the course content, other learners, the instructor, and the technological medium used in the course. True interactions with other learners, the instructor, and the technology results in a reciprocal exchange of information. The exchange of information is intended to enhance knowledge development in the learning environment. Depending on the nature of the course content, the reciprocal exchange may be absent - such as in the case of paper printed content. Ultimately, the goal of interaction is to increase understanding of the course content or mastery of the defined goals (p. 4).

Interaction with the instructor is considered to be the most significant contributor to perceived learning in online courses (Fredericksen, Pickett, Pelz, Shea, \& Swan, 2000). Research has shown that collaborative interactions with peer learners promoted higher levels of satisfaction, social interactions with instructors and better learning performance, while interactions with academic materials (student-to-content interactions) seemed to play a less significant role (Jung, Choi, Lim, \& Leem, 2002). Further research studies have shown that learner-instructor interaction is the best predictor of course satisfaction and is by far the most significant predictor of student satisfaction in web-based education (Battalio, 2007; Bolliger \& 
Martindale, 2004; Thurmond, 2003; Thurmond \& Wambach, 2004). According to Hiltz and Shea (2005), online learners' individual objectives and psychological characteristics are related to the likelihood of their success in online courses (as defined by high learner satisfaction and good grades). Moore and Kearsley (2005) opined that students in online courses begin discourse with other learners on an individual or group basis and discourse in online learning environments help students to develop skills in knowledge acquisition, which leads to academic success.

Table 1 below summarizes critical factors that affect learners' satisfaction in online education.

Table 1.

Critical Factors that Affect Learners' Satisfaction in Online Learning

\begin{tabular}{|l|l|}
\hline Author (s) & Factors \\
\hline Arbaugh (2002) & $\begin{array}{l}\text { Perceived usefulness and perceived ease of use, flexibility } \\
\text { of e-Learning, interaction with class participants, student } \\
\text { usage, and gender }\end{array}$ \\
\hline Arbaugh \& Duray (2002) & $\begin{array}{l}\text { Perceived usefulness and perceived ease of use, perceived } \\
\text { flexibility }\end{array}$ \\
\hline Piccoli, Ahmad, \& Ives & $\begin{array}{l}\text { Maturity, motivation, technology comfort, technology } \\
\text { attitudes, computer anxiety, and epistemic beliefs, } \\
\text { technology control, technology attitudes, teaching styles, } \\
\text { self-efficacy, availability, objectivist and constructivist, } \\
\text { quality, reliability, and availability, pace, sequence, control, } \\
\text { factual knowledge, procedural knowledge, conceptual } \\
\text { knowledge, timing, frequency, and quality }\end{array}$ \\
\hline Hong (2002) & $\begin{array}{l}\text { Gender, age, scholastic aptitude, learning style, and initial } \\
\text { computer skills, interaction with instructor, interaction with } \\
\text { fellow students, course activities, discussion sessions, and } \\
\text { time spent on the course }\end{array}$ \\
\hline Kanuka \& Nocente (2003) & $\begin{array}{l}\text { Motivating aims, cognitive modes, and interpersonal } \\
\text { behaviors }\end{array}$ \\
\hline Stokes (2001) & $\begin{array}{l}\text { Students' temperaments (guardian, idealist, artisan, and } \\
\text { rational) }\end{array}$ \\
\hline Thurmond, Wambach, \\
Connors, \& Frey (2002) \\
$\begin{array}{l}\text { Learning technology, live from the main campus of the } \\
\text { institution, age, receive comments promptly on time, offer } \\
\text { various assessment methods, time to spend, scheduled } \\
\text { discussions, team work, acquaintance with the instructors }\end{array}$ \\
\hline
\end{tabular}

\section{Self-Regulated Learning and Online Education}

Self-regulated learning is defined as the degree to which students are meta-cognitively, motivationally, and behaviorally active participants in their learning (Zimmerman, 1989). Several researchers have indicated the presence and importance of self-regulated learning in online learning environments (Barnard, Lan, To, Paton, \& Lai, 2009; Nicol, 2009; Paraskeva, Mysirlaki, \& Choustoulakis, 2009). Research studies (Artino, 2008; Artino \& Stephens, 2009; Barnard-Brak, Paton, \& Lan, 2010; Hodges \& Kim, 2010; Matuga, 2009; Shea \& Bidjerano, 
2010) have shown that online learning is highly student-centered, where they have to assume more responsibilities and autonomy, especially in asynchronous learning environments. For example, the more self-regulatory skills students possess, the more likely they are to be successful in online learning environments (Shea \& Bidjerano, 2010). Online learning provides students with flexibility and learner-centeredness in a setting where it is important for students to employ more self-regulatory skills (Artino, 2007; Bothma \& Monteith, 2004; Jonassen, Davidson, Collins, Campbell, \& Haag, 1995; King, Harner, \& Brown, 2000). Little research has been conducted on student satisfaction and attitudes of minority students in online learning (Artino, 2007; Peterson, 2011; Puzziferro, 2008).

\section{Diversity, Cultures, and Online Learning}

Research studies have shown that some students in online learning lack active selfdirected learning skills; thus the need to provide them with additional support or scaffolding to build those skills (Azevedo, 2005; Azevedo et al., 2004; Quintana, Zhang, \& Krajcik, 2005; Shapiro, 2000). Another study by Bork and Rucks-Ahidiana, (2013) indicated that some online instructors expect students in online courses to have a basic knowledge of self-directed learning skills. They also believed that faculty should not be responsible for helping students develop these skills. According to Chavous et al. (2003), students who possessed a positive view towards their self-identity as African-American tended to have a more positive academic performance and group identification. Results from the same study revealed that minority students' beliefs about their racial identity may be connected to their future educational attainment. Okwumabua, Walker, Hu, and Watson (2011) observed that while the majority of African-American students had positive attitudes toward computers, a significant number did not report high levels of confidence in working online. Other studies such as Ibarra (2000) and Smith and Ayers (2006) found that student groups with a high-context culture, such as Latino students, experienced disadvantages in a web-based learning environment designed with a low-context culture.

In the past two decades, online learning has seen a rapid growth among college students. However, cultural dimensions for online learning have focused specifically on the impact of students' cultural demographics on cognitive development and learning outcomes (e.g., Gunawardena, Wilson, \& Nolla, 2003). Other research areas are self-perceptions and learning experiences of cross-cultural learners (e.g., Wang, 2007), and cultural disconnection in the multicultural online learning setting (e.g., Ibarra, 2000). For instance, a study by Gay (2010) reported that faculty must be knowledgeable about the cultural differences and create an inclusive, accessible and flexible learning environment to attract minority students in online learning. Similarly, Timmis and Cook's (2004) examination of students' motivation in online learning revealed that motivation is a vital component to be considered in online courses for minority students. The above studies significantly stated that culturally related differences in students' online learning experiences influence the teaching, social, and cognitive presence and academic success of minority students. However, they failed to examine how minority students' use of technology, satisfaction, use of social media, the number of online courses, and program of study lead to their academic performance (As measured by their Grade Point Average). This article presents findings from a mixed-method study that examines the relationship between minority students' online learning experiences and academic performance. In this way, it is hoped that instructors and educators working with minority students in online environments will gain a better understanding of the varied factors that facilitate effective online instruction for these 
students.

\section{Theoretical Framework}

This study is primarily framed by stereotype threat theory. According to Steele and Aronson (1995), stereotype threat refers to being at risk of confirming, as a self-characteristic, a negative stereotype about one's social group. Steele and Aronson (1995) first used stereotype threat theory in their research that showed that Black college students performed more poorly on tests than White students when race was given prominence. However, they performed better when their race was not used as the underlined status. According to Marx and Stapel (2006), the conditions that produce stereotype threat are ones in which demonstrated stereotype connects the self in association with a relevant social category.

According to Schmader, Johns, and Forbes (2008), stereotype threat (ST) denotes a situation in which a member of a group fears that their performance will verify an existing negative performance stereotype, thereby causing a decrease in academic performance. For example, reminding minority students of the stereotype "African Americans do not perform well in SAT and GRE” causes them to perform more poorly on the Scholastic Assessment Test (SAT) or the Graduate Record Examination (GRE). Stereotype threat theory attempts to understand how negative performance stereotypes affect stigmatized group members' performance, and how activation of the stereotype produces and amplifies the resultant performance decrements (Steele, Spencer, \& Aronson, 2002).

Steele (1997) contended that stereotype threat seems to undermine academic performance achievement in two ways. First, it can impair performance by inducing anxiety in students. A typical example is the intellectual test like the GRE that is used as a measure to determine the academic performance of students. The second measure is that stereotype appears to undermine achievement through "disidentification," which refers to the process by which one redefines the self-concept such that a threatened domain is not used as a condition of self-esteem. As noted by Steele (1997), awareness of stereotype threat derives not from internal doubts about one's ability based on one's history of failure and/or the internalization of the stereotype under the influence of socialization, but from one's identification with the critical domain and the resulting concern about being stereotyped in that domain. The psychological disengagement from achievement helps minority students manage stereotype threat and underperformance in a given domain (Steele, 1997).

Research has shown that stereotype threat affects the academic performance of any individual whose situation implores a stereotype-based expectation of poor performance (Marx \& Stapel 2006). Examples of studies on stereotype threats are as follows: women's performance in math (e.g., Spencer, Steele, \& Quinn, 1999), students from low socioeconomic backgrounds compared to students from high socioeconomic backgrounds on intellectual tasks (e.g., Harrison, Stevens, Monty, \& Coakley (2006), Whites compared with Blacks and Hispanics on tasks assumed to reflect natural sports ability (e.g., Stone, 2002), and Whites compared with Asian men in mathematics (e.g., Aronson, et al., 1999). Other studies also indicated that stereotype threat undermines the academic performance of Hispanic students from low socioeconomic backgrounds (Croizet \& Claire, 1998; Gonzales, Blanton, \& Williams, 2002) and females in 
math (Good, Aronson, \& Harder, 2008).

As noted above, several factors influence an individual's "stereotype vulnerability" (Aronson, Fried, \& Good, 2002) to include domain identification, group membership, and group identification. These factors have the consequence of decreased performance in academic and non-academic domains, increased use of self-defeating behaviors of students. Likewise, Massey, Charles, Lundy, and Fischer (2003) concluded that stereotype threat is a significant component of the academic underachievement of low-status group members. The study focused on AfricanAmericans and Latinos; however, it did not specifically address the question of how stereotype threat influences the relationship between minority students' and academic performance in online learning environments.

The theoretical framework described above and chosen to undergird this study offers multiple lenses through which to assess the relationship between minority students' satisfaction and experiences with online learning and their academic performance (As measured by their Grade Point Average). Extensive research has been conducted to understand how stereotype threat affects the academic performance of minority students from different ethnic backgrounds, but little has focused on minority students' use of technology, social media, gender, age, and academic performance in online learning environment. Thus, there is the need to examine the relationship between minority students' experiences in online learning and academic performance.

\section{Methods}

This study used a mixed-methods approach as a means of inquiry that combined both qualitative and quantitative forms of research (Creswell \& Plano Clark, 2011). According to Tashakkori and Teddlie (2010), both numerical and text data, collected sequentially or concurrently, can help better understand the research problem. The purpose of this approach is to achieve greater strength than in qualitative or quantitative research study alone (Creswell, 2009). Satisfaction in online learning is an important construct regarding the various mediums through which interaction occurs in online learning. The following research questions were used to address the gaps of knowledge about the relationship between minority students' satisfaction, online learning experiences, and academic performance:

1. Is there a relationship between minority students' satisfaction and academic performance (As measured by Grade Point Average) in online learning?

2. How does satisfaction in online learning interaction predict academic performance (As measured by Grade Point Average) of minority students?

3. Is there a relationship between minority students' use of social media and academic performance (As measured by Grade Point Average)?

4. Is there a relationship between minority students' use of technology and academic performance (As measured by Grade Point Average) in online learning?

5. Is there a relationship between minority students' academic performance and the number of online courses taken?

6. Is there a relationship between minority students' program of study and academic performance in online learning? 


\section{Data Source Sample}

\section{Site and participants}

The participants in this study were 149 minority college students comprising of 86 males and 63 females who had enrolled in various online courses at a major university in the Southeastern United States. The average age of participants was between 20 to 36 years and above (see Tables 1 and 2 for demographic information of students). Participants were recruited with the help of the Multicultural Students Association and the Information Technology Center at the university in which the study was based. Participants were minority students from one of the following categories: African American, Hispanic, Asian, Native American, or Pacific Islander, including international students. All of the participants had enrolled in at least one or more online courses at both undergraduate and graduate levels. The courses were full-credit online courses and shared the following features: 1) a diverse student body in terms of age, ethnic status, and education level; 2) a requirement of learner participation in online discussions, which represented more than 35\% of the students' study time; and 3) online instructors with an average of three years of online instruction experience. Participants were in the colleges of Arts and Sciences, Education, Engineering, Health Sciences, and Humanities.

\section{Procedures}

With permission from the Office of Multicultural Students Association and the Information Technology Center at the major university in the Southeastern United States, we accessed minority students' e-mail addresses in a search for prospective participants for the study. First, we sent two emails to participants during a period of one month to update them about the purpose of the study. Additionally, participants were assured of their confidentiality of information.

The online survey was set up to provide access for participants to complete the survey within a period of one month. We received minimal responses from students, and this prompted a second email to students. We also sent an email to remind students of the time limit to complete survey. This increased the response rate to more than $60 \%$. Students received no compensation for their participation in the study. In addition to these procedures, 25 additional students were recruited in a manner similar to the one described previously for the sole purpose of pilot testing. This population consisted of 15 male and ten female minority college students who had taken two or more online courses at the time of the pilot study. Overall, excluding the pilot group, 158 students of the 170 students who received the invitation completed the online survey. However, due to inconsistencies of information in some of the surveys, nine students were not included in the coding and analysis for this study.

\section{Data Analyses}

Data was analyzed through the use of the Statistical Package for Social Sciences (IBM SPSS Statistics version 20.0). First, a data screening of results was conducted to confirm accurate results of the data. Descriptive statistics of variables in the survey were summarized and presented in a tabular form. Analysis of frequency was performed to determine percentage responses to questions in the survey. One-Way Analysis of Variance (ANOVA) and Chi-square tests was used to determine whether there are any significant differences between minority students' satisfaction, use of technology, social media, the number of online courses, and academic performance (GPA) in online education. One-Way Analysis of Variance (ANOVA) 
was chosen determine the differences between the means of three or more independent (unrelated) groups. With regards to the open-ended response questions, we read through all the 149 open-ended questions with the help of three peer reviewers to accomplish and maintain triangulation of all themes through our iterative and qualitative analytical examination of the data.

\section{Results}

\section{Descriptive Analysis}

The purpose of the study was to examine the relationship between minority students' use of technology, satisfaction, use of social media, the number of online courses, program of study, and academic performance (As measured by Grade Point Average). Table 2 shows the frequency distribution of participants by age group. Participants between the ages of 20 and 25 years old accounted for 40.27\% followed by those between 26 and 30 years, 36.91\%; 31 and 35 years, 14.09\%; and 36 years and above, $8.72 \%$. Analysis of data showed that the majority of participants were between 20-25 and 26-30 years of age. The frequency distribution of 36 years and above was small (8.72\%).

Table 2.

Age of Participants

\begin{tabular}{lcc}
\hline Age group & $n$ & Percent \\
\hline $20-25$ & 60 & $40.27 \%$ \\
$26-30$ & 55 & $36.91 \%$ \\
$31-35$ & 21 & $14.09 \%$ \\
$36+$ & 13 & $8.72 \%$ \\
\hline
\end{tabular}

Note. $N=149$

Table 3 depicts the number of online courses by participants. As seen in Table 3, the percentage of students who had taken one or more online courses was $27.5 \%$ and $72.48 \%$ for those who taken three or more online courses.

Table 3.

Number of Online Courses by Participants

\begin{tabular}{lll}
\hline $\begin{array}{l}\text { Number of Online } \\
\text { Courses }\end{array}$ & $n$ & Percent \\
\hline $1-2$ Courses & 41 & $27.52 \%$ \\
\hline $3+$ Courses & 108 & $72.48 \%$ \\
\hline Note. $N=149$
\end{tabular}

Note. $N=149$

Table 4 presents the frequency distribution of participants by program of study. Participants in Arts and Sciences accounted for 11.41\%; Education 27.52\%; Engineering 32.21\%; Health Sciences 20.13\%, and Humanities 8.72\%. The data in Table 4 shows that the College of Engineering (32.21\%) received more participants in the program of study. 
Table 4.

Program of Study

\begin{tabular}{lcc}
\hline Program & $n$ & Percent \\
\hline Arts \& Sciences & 17 & $11.41 \%$ \\
\hline Education & 41 & $27.52 \%$ \\
\hline Engineering & 48 & $32.21 \%$ \\
\hline Health Sciences & 30 & $20.13 \%$ \\
\hline Humanities & 13 & $8.72 \%$ \\
\hline Note. $N=149$ & &
\end{tabular}

Table 5 indicates the frequency distribution of the academic standing of participants. As seen in Table 5, minority graduate students accounted for the largest with $30.20 \&$ followed by seniors, 28.19\%; Juniors, 24.16\%; and Sophomores $17.45 \%$.

Table 5.

Academic Standing of Participants

\begin{tabular}{lll}
\hline Academic Standing & $n$ & Percent \\
\hline Sophomore & 26 & $17.45 \%$ \\
\hline Junior & 36 & $24.16 \%$ \\
\hline Senior & 42 & $28.19 \%$ \\
\hline Graduate & 45 & $30.20 \%$ \\
\hline
\end{tabular}

Note. $N=149$

Table 6 presents the academic performance of minority students in an online course from the lowest 1.5 to highest (GPA) 4.0. Students who fell within the 3.0 to 3.49 group accounted for the highest percentage with $38.93 \%$ followed by $26.17 \%$ for students with a GPA within 2.5 to 2.99; $23.49 \%$ for students with a GPA 3.5 to 4.0 ; and $11.41 \%$ for those with a GPA of 1.5 to 1.99 .

Table 6.

Academic Performances (Based on Grade Point Average) of Participants

\begin{tabular}{lll}
\hline $\begin{array}{l}\text { Grade Point Average } \\
\text { (GPA) }\end{array}$ & $n$ & Percent \\
\hline $3.5-4.0$ & 35 & $23.49 \%$ \\
\hline $3.0-3.49$ & 58 & $38.93 \%$ \\
\hline $2.5-2.99$ & 39 & $26.17 \%$ \\
\hline $1.5-1.99$ & 17 & $11.41 \%$ \\
\hline
\end{tabular}

Note. $N=149$

Table 7 displays the percentage distribution of Means and Standard Deviation of minority students' satisfaction in online learning by overall (As measured Grade Point Average) grade point average. The Mean for minority students within the GPA of 3.5 to 4.0 was $4.057(M=$ 4.057), followed by 3.793( $M=3.793)$ for those with GPA of 3.0 to 3.49 ; 3.871 $(M=3.871)$ for GPA group of 2.5 to 2.99; and 3.823( $M=3.823)$ for students with a GPA of 1.5 to 1.99. Data 
showed that most students were within the highest GPA range of 3.5 to 4.0 indicating selfefficacy of academic achievement as a result of online course.

Table 7.

Means and Standard Deviation of Participants Satisfaction in Online Learning by Overall Grade Point Average

\begin{tabular}{cccc}
\hline $\begin{array}{c}\text { Overall } \\
\text { GPA }\end{array}$ & $n$ & $M$ & $S D$ \\
\hline $3.5-4.0$ & 35 & 4.05 & 0.83 \\
$3.0-3.49$ & 58 & 3.79 & 1.22 \\
$2.5-2.99$ & 39 & 3.87 & 0.92 \\
$1.5-1.99$ & 17 & 3.82 & 1.18 \\
\hline
\end{tabular}

Note. $N=149$

Table 8 displays One-Way Analysis of Variance (ANOVA) of minority students' satisfaction in online learning. ANOVA tests were used to investigate the relationships between minority students' satisfaction and academic performance (As measured by Grade Point Average) in online learning. A One-Way Analysis of Variance showed that there was no significant relationship between minority students' satisfaction and academic performance (Grade Point Average) in online learning at the $p>0.5$ level for the four groups, $(3,145)=0.47, p=0.070$. Results showed that minority students' satisfaction in online learning does not predict higher academic achievement.

Table 8.

One-Way Analysis of Variance of Minority Students’ Satisfaction in Online Learning

\begin{tabular}{llllll}
\hline Source & $d f$ & $S S$ & $M S$ & $F$ & $P$ \\
\hline $\begin{array}{l}\text { Between- } \\
\text { groups }\end{array}$ & 3 & 1.592 & 0.53 & 0.47 & 0 \\
& & & & & .7 \\
$\begin{array}{l}\text { Within-groups } \\
\text { Total }\end{array}$ & 145 & 164.23 & 1.13 & & \\
\hline
\end{tabular}

Note. $N=149$

A One-Way Analysis of Variance (ANOVA) was used to test the relationship between use of social media and academic performance of minority students. Results indicated no significant relationship between minority students' use of social media and academic performance (As measured by Grade Point Average) at $p>.05$ for the four groups, F $(3,145)=0.49, p=0.692$. Findings showed that minority students' use of all forms of social media did not predict academic performance in online learning. 
Table 9.

One-Way Analysis of Variance Between Minority Students’ Use of Social Media and Academic Performance (GPA)

\begin{tabular}{llllll}
\hline Source & $d f$ & $S S$ & $M S$ & $F$ & $P$ \\
\hline $\begin{array}{l}\text { Between- } \\
\text { groups }\end{array}$ & 3 & 1.693 & 0.564 & 0.49 & 0.692 \\
\hline Within-groups & 145 & $\begin{array}{l}168.48 \\
0\end{array}$ & 1.161 & & \\
\hline Total & 148 & $\begin{array}{l}170.17 \\
4\end{array}$ & & & \\
\hline
\end{tabular}

Note. $N=149$

Table 10 presents One-Way Analysis of Variance (ANOVA) to test the relationship between use of technology in an online course and academic performance of minority students. There was significant relationship between minority students' use of technology and academic performance (As measured by Grade Point Average) for the four groups at $p<0.03$ for the four groups, F (3, $145)=2.88, p=0.038$. Results from the data indicated that minority students' use of technology in online course largely influenced their academic achievement.

Table 10.

A One-Way Analysis of Variance Between Minority Students’ Use of Technology and Academic Performance (GPA) in Online Learning

\begin{tabular}{llllll}
\hline Source & $d f$ & $S S$ & $M S$ & $F$ & $P$ \\
\hline $\begin{array}{l}\text { Between- } \\
\text { groups }\end{array}$ & 3 & 8.466 & 2.82 & 2.88 & 0.03 \\
\hline Within- groups & 145 & 142.32 & 0.98 & & \\
\hline Total & 148 & & & & \\
\hline Note $N=149$ & & & &
\end{tabular}

Note. $N=149$

Further, a chi-square test of independence was performed to determine the relationship between minority students' academic performance (As measured by Grade Point Average) and the number of online courses taken. A test of relationship showed that there was statistically significant relationships existed between academic performance of students' and number of online courses taken with a $p$-value of $0.35, \chi^{2}(3)=3.220, p=0.35$ and a relatively small effect size (Cohen's $w=0.1470)$. A chi-square test of the relationship between minority students' program of study (education, arts and sciences, engineering, health, and humanities) in online courses and academic performance indicated a significant association between program of study and academic performance of minority students' in online learning with a $p$-value of $0.2, \chi^{2}(4)=$ 15.041, $p=0.2$ and a relatively small effect size (Cohen's $w=0.1834$ ).

\section{Open-Ended Questions}

The purpose of the open-ended questions was to gather additional information from participants and extend the results of the quantitative data. Minority students were asked to provide additional information with regards to experiences in online courses as related to 
academic achievements in written statements. We read through all the 149 open-ended responses with the help of three peer reviewers. Open-ended questions were "What are your primary reasons for choosing online courses?", "What do you like most about online courses?”, "What do you like least about online courses?", and "What advice would you give to students new to online courses?" After thorough reviews of all responses, we identified the following categories from the open-ended response questions: flexibility and time convenience, self-confidence in discussion posts, lack of support, language and linguistics differences (cultural), and lack of selfregulated learning skills through the iterative and analytical examination of the data.

With respect to flexibility and time convenience, a participant commented:

I had plenty of time with all my online courses. You get flexibility and time to prepare and submit my assignment and projects. I had good grades because of the time and convenience as compared to my face-to-face courses. I do have enough time to contribute to class discussions; I feel like I have time to respond to other students' comments to understand and comprehend concepts. Overall, I am getting good grades in my online courses.

Another student commented:

Surely, taking an online course to me is very convenient for me; you have time to do course assignments. I do not have to travel to campus for class at a specified time and will only have to complete my assignments on the modules at the due dates for all online class assignment. I have more time to do thorough readings before class. I think it's the best teaching strategy for me to manage my course work. I get good grades in online learning courses because of the flexibility and time to manage assignments.

Concerning written responses to self-confidence in class discussion, a participant noted:

With online course, I have the opportunity to make contributions to discussion posts without any embarrassment of what I would say or not. It gives you an equal chance to post your comments and response as well, unlike the face-to-face class. I believe I have developed self-confidence to and make my opinion heard in class. My confidence level in online discussion board is high because there is no pressure about your culture and ethnic background.

Online learning provides minority students the opportunity to be proactive in online discussion posts. According to Gay (2010), faculty must be knowledgeable about cultural differences and create an inclusive, accessible and flexible learning environment to attract minority students in online learning. The majority of the participants indicated that they develop self-confidence in online discussions that ultimately leads them to improve their academic performance.

A student observed: 
I think taking online classes has provided me the opportunity to express my opinions in online discussion without any fear of acceptance or mockery of your comments or fear of ridicule by other students because of my cultural and language differences. My presence is profoundly felt in online classes than on face-to-face. My professors give me high grades on discussion posts in online class. I usually do not better grades on classroom discussion in face-to-face class. Genuinely, I like the online course because of the confidence I develop to make my voices heard in online and of course, the grade as well.

Regarding the lack of support from online instructors with specific a focus on Course Management Systems (CMS) and Learning Management Systems (LMS). A participant stated:

I feel like I don’t get enough support from my instructors about how to navigate to find course information. There was no formal orientation on how to find course information and especially about discussion posts and submission of assignment into the "Dropbox" I struggled initially to learn the process, this affected me because I took a lot of time to figure it myself. I also struggled on both the LMS and CMS especially navigating around the block to locate and submit my assignment(s). Rarely had any better support from instructors and others. Takes time to get support from the IT center.

Another student expressed his experience, saying:

I would say that I missed lot of assignment deadlines because I had no refresher orientation on what to do before the course started by the instructor - had to find information on Blackboard myself. It was very challenging and frustrating I would say.

It's just like the traditional classroom instructors must understand the cultural and language backgrounds of students in an online medium, so that I don't have to struggle in online learning.

Regarding language challenges, a participant described her experiences, indicating:

As a second language learner [ELL] and a multilingual student, it was a challenge understanding some of the materials in my online course, I needed more explanation but there was none as compared to my face-to-face classes, and it affected my grades in almost all online courses I have taken.

Another student learner whose first language was not English commented:

I face challenges in the online course because of my language and cultural background. For example, I had a frosty relationship with one instructor in last Fall semester, because she kept giving me lower grades because there was a lot of cultural differences in online discussion posts. The instructor and some of my 
peers understood most of what I posted, probably due to the contextual meanings of my postings, though, not all the times.

As indicated in the literature review, Okwumabua et al. (2011) stated that minority students tend to display differently in attitudinal and behavioral aspects of online learning. Second, inequities develop that arise from dominant cultural values embodied in teaching materials and methods (e.g., Gunawardena et al., 2003) and miscommunication among students in online interactions arising from cultural difference (e.g., Wong \& Trinidad, 2004).

Lastly, the majority of the students complained of lack of self-regulated learning skills in online courses. One student noted:

With all the online courses I have taken so far, my biggest challenge is the ability to manage my time with other school related work. I don't have the skills of regulating my time with Internet space to complete all tasks. I'm aware that I have to be responsible for online learning but the task to do it is too much for me sometimes I get confused. It has affected my grades in my online courses.

According to Artino (2008), in online learning, students assume greater responsibilities and autonomy, especially in asynchronous learning environments. Online learning provides students with flexibility, and its learner-centeredness requires students to employ more selfregulatory skills (Artino, 2007; Bothma \& Monteith, 2004; Jonassen et al., 1995; King et al., 2000). Integration of the two data sets revealed that satisfaction in an online course and use of social media had no relationship with the academic performance of minority students, while the use of technology, the number of courses taken online, program of study, flexibility and time convenience, and self-confidence positively influenced the academic performance of students. However, lack of support, language and linguistic differences, and lack of self-regulated learning skills affected the academic achievements of students negatively.

\section{Discussion}

The study found that there was a relationship between minority students' online learning experiences and academic performance regarding the use of technology, the number of courses in online, and program of study. However, there was no relationship between minority students' satisfaction in online courses, use of social media and academic performance. Responses from the open-ended questions indicated that flexibility and time convenience, self-confidence in discussion posts, lack of support, language and linguistics differences (cultural), and lack of selfregulated learning skills influenced the academic performance of these learners. Findings from the study indicated that factors such as flexibility, time convenience, and self-confidence positively influenced the academic performance of minority students. However, factors such as linguistic differences of minority students in an online course, lack of self-regulated learning skills, and a lack of support mostly affected the academic achievements of minority students. This is consistent with Ke and Carr-Chellman's (2003) study that there is a need to create diverse online learning interactions for students, particularly minority students with limited English and social presence in online education. Several research studies have shown that student-instructor interaction is the best predictor of course satisfaction, and learner-instructor interaction is by far 
the most significant predictor of student satisfaction in web-based education (Battalio, 2007; Bolliger \& Martindale, 2004; Thurmond, 2003).

Overall, quantitative results from the data showed that there was no significant relationship between minority students' satisfaction in online learning and academic performance (As measured by Grade Point Average). It appears that satisfaction in learning during an online course by minority students has no positive impact on minority students' academic performance. It could be that minority students' satisfaction in online learning stems from better interaction with instructors and peers in online learning environment but lacks understanding of the concepts that help them to enhance their academic performance based on tests, quizzes, and exams. This is inconsistent with previous studies that claimed that interactions between instructors-student and students-students promoted student satisfaction and academic performance in online learning environment (Bernard et al., 2009; Bray et al., 2008; Burnett, 2001; Juwah, 2006; Moore \& Kearsley, 2005; Northrup, Lee, \& Burgess, 2002; Thurmond \& Wambach, 2004).

The two data sets (quantitative and open-ended questions) showed that multiple factors help to facilitate academic performance of minority students in online education.

For example, our findings concluded that there was no relationship between minority students' satisfaction in online learning and academic performance. Another significant finding from the data is that the use of social media did not influence the academic performance of minority students in online learning environments. It appears that minority students used social media for personal and social purposes and not for academic tasks. Findings from the data show that the number of online courses taken by minority students was highly related to minority students' academic performance. This was due to their familiarity and experiences gained from student-instructor interactions and support in online courses. Students also may have experienced gains from LMS and CMS use that had the capacity to improve their self-regulated online learning skills. For example, several research studies indicated that student-instructor interaction is the best predictor of student satisfaction in online course (Battalio, 2007; Bolliger \& Martindale, 2004; Thurmond, 2003).

Results from the data indicated a significant relationship between program of study and academic performance of minority students in an online course. Most minority students indicated in the open-ended questions that they have positive attitudes and confidence in discussion forums in online learning course. Findings agreed with Chavous, et al. (2003) that minority students who possess positive views towards their self-identity tend to have more positive academic performance and group identification. It is also consistent with Steele's (1997) study on stereotype threat that when the concept of race was not mentioned in the process of examinations or tests, minority students performed better and identically to White students on tests or exams. However, findings disagreed with certain elements of the stereotype threat theory because the majority of the students did not mention race as a major factor that influenced their academic performance in online learning but rather socio-cultural and language factors. As noted by Steele (1997), awareness of stereotype threat derives not from internal doubts about one's ability based on one's history of failure and/or the internalization of the stereotype under the influence of socialization but from one's identification with the critical domain and the resulting concern about being stereotyped in that domain. 
Findings from the open-ended questions indicated that minority students' experienced flexibility and time convenience, confidence in discussion posts, language and linguistics differences, lack of self-regulated learning skills and lack of support. The majority of students (136 out of 149) agreed that online learning offered them flexibility and time convenience, which helped them to improve their academic performance in online courses. For example, through online courses, minority students had ample time and flexibility to prepare and submit their assignments. Several studies (Artino, 2007; Bothma \& Monteith, 2004; Jonassen et al., 1995; King et al., 2000) contended that flexibility and learner-centeredness helped students to develop more self-regulatory skills to facilitate their academic success. In this study, most minority students (132 out of 149) indicated that the interactive nature of online learning provided them confidence and the opportunity to make contributions in discussion posts. They described how online learning gave them the opportunity to express themselves without fear of any embarrassment from peers and instructors who hardly understand their cultural frame of reference. This is consistent with other studies (Hong, 2002; Jiang \& Ting, 1998) that contended that factors such as gender, age, scholastic aptitude, learning style, initial computer skills, interaction with instructor, interaction with fellow students, course activities, discussion sessions, and time spent on the course help facilitate students' academic performance. Results agreed with Sher (2009) study that student-to-student and student-to-instructor interactions were significant contributors to the levels of student learning and satisfaction in an online learning environment.

A large number of minority students (134 out of 149) expressed that they received little or no support from their online instructors because they had few or no skills in how to manage and regulate course management systems and because they needed additional support. Minority students expressed that a lack of support from some instructors affected their understanding and the way to navigate through the course management system and ability to interact with other students and faculty. They indicated that the above factors led them to receive low academic performance. The findings confirmed that students who did not have adequate access to their instructors were less satisfied with their online courses. According to Jiang and Ting (1998), online instructor's support for students plays a significant role in increasing students' participation in online learning. Findings from the open-ended questions agreed with Steele and Aronson's (1995) assertion that negative stereotypes about one's social group may undermine an individual's academic performance. For instance, the majority of the minority students (135 out of 149) mentioned that issues with cultural differences such as miscommunication, negative perception, and misunderstandings with some instructors and peers during discussion forums negatively affected their academic performance. According to Goodfellow and Hewling (2005), cultural challenges in online learning environment can arise from the development of inequities embedded in dominant cultural values that are reflected in teaching materials and methods (e.g., Gunawardena et al., 2003). It also lends credence to research suggesting that potential miscommunication among participants during online interactions can arise from the cultural differences of minority students (e.g., Wong \& Trinidad, 2004).

Additionally, several minority students (124 out of 149) indicated that they lacked selfregulated learning skills for online learning. They explained that they had issues such as time management, the ability to submit discussion posts, projects, assignments, and the ability to regulate the time around course completion efficiently. This evidence confirms that the flexibility, demanding nature, and learner-centeredness of online learning require students to employ greater self-regulatory skills (Artino, 2007; Bothma \& Monteith, 2004; Jonassen et al., 
1995; King et al., 2000).

Overall, the two data sets (quantitative and open-ended questions) indicated that multilayered factors facilitate and challenging factors influence the academic performance of minority students in online learning. Findings from the study also showed that the use of social media and satisfaction with online learning had no influence on minority students' academic achievement in online learning environments. However, the use of technology in different forms and the number of online courses taken highly impacted minority students' academic performance.

A major implication from this study is that instructors who teach online must understand the varied cultures, lived experiences, and socio-linguistic backgrounds of the students they teach. Instructors also must recognize and understand that several factors (motivation, sociolinguistic, culture, self-efficacy, self-regulated learning skills, and basic computer knowledge) influence the academic performance of minority students in the online learning environment. Online instructors must be aware of and knowledgeable about cultural differences and create an inclusive, accessible and flexible learning environment to attract and promote better academic performance from minority students in online learning (Gay, 2010). Theoretically, this study suggest that greater attention should be devoted to laying the groundwork for developing online courses that take into account cultural diversity and allow instructors, educators, and students to build relationships that lead to better academic performance from minority students. Another implication of this study is that online instructors need to provide appropriate support if it is suspected that culturally-related factors might negatively affect minority students in their online learning experiences. A major significance of this study is that it informs instructors who teach online courses about the best pedagogical practices for promoting multicultural presence in the interest of promoting the educational needs of minority students in online learning environments.

\section{Limitations}

Several limitations were present in the study. The first limitation was that the sample size of 149 participants was selected from only one major university. Ideally, a higher participation rate from several universities would have allowed for more diverse opinions. Another limitation of the study was that the survey did not include interviews with minority students. Data collected consisted of only quantitative and open-ended questions from minority students. A qualitative interview would have generated additional information from the participants as related to online learning experiences and academic performance. The second major limitation was that study was devoid of faculty opinions. Including faculty views about ways to promote student satisfaction with online learning would have broadened the nature of the results of the study. Furthermore, this study did not take into account the satisfaction and online learning experiences of minority students from other universities across the United States. The scope and range of the researchers' information limited the researchers from making any conclusions about minority students in other universities. Furthermore, this study was limited to minority students from the colleges of Arts and Sciences, Education, Engineering, Health Sciences, and Humanities; the researchers could not generalize the results to other colleges at the university. The data is useful because it suggested that there is a relationship between minority students' use of technology, the number of courses in online, program of study, and academic performance. Future research could examine the factors that promote the academic performance of minority students' in online 
learning environment. Another study could focus on instructor-student and student-faculty interactions in online learning environments and how they influence the academic performance of minority students. Furthermore, additional research in this field could include expanding this study by including more than one university to highlight minority students' online learning experiences and how their experiences affect their academic performance.

\section{Conclusion}

In conclusion, the study revealed that there was a relationship between the use of technology, the number of online courses, the program of study, and the academic performance of minority students in an online learning environment. However, satisfaction in online learning had no influence on the academic performance of minority students in an online learning environment. Open-ended questions also indicated that flexibility, time convenience, and selfconfidence highly facilitated the academic performance of minority students. Success in an online learning environment requires minority students to assume responsibility for all course management skills, possess prior knowledge of information technology skills, have the capacity to manage time and schedules, and meet basic requirements for undertaking an online course. Instructors who teach online courses should not have a one-dimensional approach, and they should not assume that minority students in online learning will have the ability to self-regulate to understand how to navigate through the LMS and CMS without the support from faculty. Just like traditional face-to-face classes, students in online environments bring different cultures, language, learning styles, experiences, and educational backgrounds into the instructional setting. Therefore, faculty must make an effort to incorporate diversity into their curriculum to support and meet the needs of all students. Findings also demonstrated that factors such as a lack of support, cultural differences, and a lack of self-regulated learning skills affected the academic achievement of minority students. Additionally, this study has shown that the ability to use technology in varying forms plays an important role in the academic performance of minority students. This research captured how multicultural presence (valuing the socio-cultural differences and recognizing and respecting the presence of all diverse groups in the virtual classroom) contributes to the academic performance of minority students in an online learning environment. 


\section{References}

Adeoye, B., \& Wentling, R. M. (2007). The relationship between national culture and the usability of an e-learning system. International Journal of E-Learning, 6(1), 119-146.

Allen, I. E., \& Seaman, J. (2008). Class differences: Online education in the United States, 2010. Needham, MA: Babson Survey Research Group.

Allen, I. E., \& Seaman, J. (2014). Class differences: Online education in the United States. Needham, MA: Babson Survey Research Group. Retrieved February 4, 2015 https://www.sloan c.org/publications/survey/pdf/sizing_opportunity.pdf

Arbaugh, J. B. (2002). Managing the on-line classroom: a study of technological and behavioral characteristics of web-based MBA courses. Journal of High Technology Management Research, 13, 203-223.

Arbaugh, J. B., \& Duray, R. (2002). Technological and structural characteristics, student learning and satisfaction with web-based courses-An exploratory study of two on-line MBA programs. Management Learning, 33(3), 331-347.

Aronson, J., Fried, C. B., \& Good, C. (2002). Reducing the Effects of Stereotype Threat on African American College Students by Shaping Theories of Intelligence. Journal of Experimental Social Psychology, 38, 113-125.

Aronson, J., Lustina, M. J., Good, C., Keough, K., Steele, C. M., \& Brown, J. (1999). When White Men Can't Do Math: Necessary and Sufficient Factors in Stereotype Threat. Journal of Experimental Social Psychology, 35, 29-46.

Artino, A. R. (2007) Online military training: Using a social cognitive view of motivation and self-regulation to understand students' satisfaction, perceived learning, and choice. Quarterly Review of Distance Education 8(3), 191-202.

Artino, A. R. (2008). Promoting academic motivation and self-regulation: Practical guidelines for online instructors. TechTrends, 52(3), 37-45.

Artino, A. R., \& Stephens, J. M. (2009). Academic motivation and self-regulation: A comparative analysis of undergraduate and graduate students learning online. Internet and Higher Education, 12, 146-151.

Astin, A. W. (1993). What matters in college? Four critical years revisited. San Francisco, CA: Jossey-Bass.

Azevedo, R. (2005). Using hypermedia as a metacognitive tool for enhancing student learning. The role of self-regulated learning. Educational Psychologist, 40 (4), 199-209. 
Azevedo, R., Cromley, J. G., \& Seibert, D. (2004). Does adaptive scaffolding facilitate students' ability to regulate their learning with hypermedia. Contemporary Educational Psychology, 29, 344-370.

Barnard-Brak, L., Paton, V. O., \& Lan, W. Y. (2010). Self-regulation across time of firstgeneration online learners. Research in Learning Technology, 18(1), 61-70.

Barnard, L., Lan, W. Y., To, Y. M., Paton, V. O., \& Lai, S. L. (2009). Measuring self-regulation in online and blended learning environments. The Internet and Higher Education, 12, 16.

Battalio, J. (2007). Interaction online: A re-evaluation. Quarterly Review of Distance Education, 8(4), 339-352.

Bollinger, D. U., \& Martindale, T. (2004). Key factors for determining student satisfaction in online courses. International Journal on E-Learning, 3(1), 61-67.

Bork, R. H., \& Rucks-Ahidiana, Z. (2013). Role ambiguity in online courses: An analysis of student and instructor expectations. (CCRC Working Paper No.64). New York: Columbia University, Teachers College, Community College Research Center.

Bothma, F., \& Monteith, J. (2004). Self-regulated learning as a prerequisite for successful distance learning. South Africa Journal of Education, 24(2), 141-147.

Brown, B. W., \& Liedholm, C. E. (2002). Can web courses replace the classroom in principles of microeconomics? The American Economic Review, 92(2), 444-448.

Chavous, T. M., Debra, H. B., Schmeelk-Cone, K., Caldwell, C. H., Kohn-Wood, L. L., \& Zimmerman, M. A. (2003). Racial identity and academic attainment among African American adolescents. Child Development, 74(4), 1076.

Coates, D., Humphreys, B. R., Kane, J., \& Vachris, M. A. (2004). "No significant distance" between face-to-face and online instruction: Evidence from principles of economics. Economics of Education Review, 23, 533-546.

Corbeil, J. R. (2003). Online technologies, self-efficacy, self-directed learning readiness, and locus of control of learners in a graduate-level web-based distance education program. (Unpublished doctoral dissertation). University of Houston, Houston, TX.

Creswell, J. W., \& Plano Clark, V. L. (2011). Designing and conducting mixed methods research. (2nd ed.). Thousand Oaks, CA: Sage.

Creswell, J. W. (2009). Research design: Qualitative, quantitative, and mixed methods approaches. (2nd ed.). Thousand Oaks, CA: Sage. 
Croizet J. C., Claire, T. (1998). Extending the concept of stereotype and threat to social class: The intellectual underperformance of students from low socioeconomic backgrounds. Personality and Social Psychology Bulletin, 24, 588-594.

Eom, S. B., Wen, H. J., \& Ashill, N. (2006). The determinants of students’ perceived learning outcomes and satisfaction in university online education: An empirical investigation. Decision Sciences Journal of Innovative Education, 4(2), 215-235.

Fredericksen, E., Pickett, A., Pelz, W., Shea, P., \& Swan, K. (2000). Student satisfaction and perceived learning with online courses: principles and examples from the SUNY Learning Network. Journal of Asynchronous Learning Networks, 14(2).

Gay, G. (2010). Acting on beliefs in teacher education for cultural diversity. Journal of Teacher Education, 61(1-2), 143-152. doi:10.1177/0022487109347320.

Green, K. (2007). The 2007 campus computing survey. Retrieved January 17, 2015 from http://www.campuscomputing.net/sites/www.campuscomputing.net/files/2007CCP_0.pdf.

Gonzales, P. M., Blanton H., \& Williams, K. J. (2002). The effects of stereotype threat and double-minority status on the test performance of Latino women. Personality and Social Psychology Bulletin, 28, 659-670.

Good, C., Aronson, J., \& Harder, J. A. (2008). Problems in the pipeline: Stereotype threat and women's achievement in high-level math courses. Journal of Applied Developmental Psychology, 29, 17-28.

Guglielmino, L. M., \& Guglielmino, P. J. (2002). Learner characteristics affecting success in electronic distance learning. In H.B. Long \& Associates, Twenty-First Century Advances in Self-Directed Leaning. Boynton Beach, FL: Motorola University Press

Gunawardena, C., Wilson, P., \& Nolla, A. (2003). Culture and online education. In M. Morre, \& W. Anderson (Eds.), Handbook of distance education (pp. 753-775). Mahwah, NJ: Lawrence Erlbaum.

Hannafin, M. J., \& Land, S. M. (1997). The foundations and assumptions of technology enhanced student-centered learning environments. Instructional Science, 25, 167-202.

Harrison, L. A., Stevens, C. M., Monty, A. N., \& Coakley, C. A. (2006). The consequences of stereotype threat on the academic performance of white and non-white lower income college students. Social Psychology of Education, 9, 341-357.

Hawkins, B. L., \& Rudy, J. A. (2008). EDUCAUSE core data service fiscal year 2007 summary report. Retrieved January 10, 2015 from http://net.educause.edu/ir/library/pdf/PUB8005.pdf. 
Hiltz, S. R., \& Shea, P. (2005). The student in the online classroom. In S. R. Hiltz \& R. Goldman (Eds.), Learning together online: Research on asynchronous learning networks (pp. 145168). Mahwah, NJ: Erlbaum.

Hodges, C. B., \& Kim, C. (2010). Email, self-regulation, self-efficacy, and achievement in a college online mathematics course. Educational Computing Research, 43(2), 207-223.

Hong, K. S. (2002). Relationships between students' and instructional variables with satisfaction and learning from a Web-based course. Internet and Higher Education, 5, 267-281.

Hughes, H., \& Bruce, C. (2006). Cultural diversity and educational inclusivity: International students' use of online information. International Journal of Learning, 12, (9), 33-40.

Ibarra, R. (2000). Studying Latinos in a "virtual" university: Reframing diversity and academic culture change. Occasional Paper No. 68. Latino Studies Series. East Lansing, MI: Julian Samora Research Institute, Retrieved March 3, 2015, from ERIC database.

Jiang, M., \& Ting, E. (1998). Course design, instruction, and students' online behaviors: A study of instructional variables and student perceptions of online learning. In Paper presented at the annual meeting of the American Educational Research Association, San Diego, CA, April 13-17, 1988

Jonassen, D. H., Davidson, M., Collins, M., Campbell, J., \& Haag, B. B. (1995). Constructivism and computer-mediated communication in distance education. American Journal of Distance Education, 9(2), 7-25.

Jung, I., Choi, S., Lim, C., \& Leem, J. (2002). Effects of different types of interaction on learning achievement, satisfaction and participation in web-based instruction. Innovations in Education \& Teaching International, 39(2), 153-162.

Kanuka, H., \& Nocente, N. (2003). Exploring the effects of personality type on perceived satisfaction with web-based learning in continuing professional development. Decision Education, 24(2), 227-245.

Ke, F., \& Carr-Chellman, A. (2006). Solitary learner in online collaborative learning: a disappointing experience. Quarterly Review of Distance Education, 7(3), 249-265.

King, F. B., Harner, M., \& Brown, S. W. (2000). Self-regulatory behavior influences in distance learning. International Journal of Instructional Media, 27(2), 147-156.

Kearsley, G. (2002). Is online learning for everybody. Educational Technology, 42(1), 41-44.

Means, B., Toyama, Y., Murphy, R., Bakia, M., \& Jones, K. (2009). Evaluation of evidencebased practices in online learning: A meta-analysis and review of online learning studies. Washington, DC: US Department of Education. 
Massey, S. D., Charles, C. Z., Lundy, G. F., \& Fischer, M. J. (2003). The source of the river: The social origins of freshmen at America's selective colleges and universities. Princeton, NJ: Princeton University Press.

Marx D. M., \& Stapel D. A. (2006). It's all in the timing: Measuring emotional reactions to stereotype threat before and after taking a test. European Journal of Social Psychology, 36, 687-698.

Matuga, J.M. (2009). Self-regulation, goal orientation, and academic achievement of secondary students in online university courses. Educational Technology \& Society, 12(3), 4-11.

Moore, M. G., \& Kearsley, G. (2005). Distance education: A systems view (2nd ed.). Belmont, CA: Wadsworth.

Nicol, D. (2009). Assessment for learner self-regulation: Enhancing achievement in the first year using learning technologies. Assessment \& Evaluation in Higher Education, 34(3), 335352.

Okwumabua, T. M., Walker, K. M., Hu, X., \& Watson, A. (2011). An exploration of African American students' attitudes toward online learning. Urban Education, 46, 241-250.

Paraskeva, Mysirlaki, \& Choustoulakis (2009). Designing collaborative learning environments using educational scenarios based on self-regulation. International Journal of Advanced Corporate Learning, 2(1), 42-49.

Peterson, S. (2011). Self-regulation and online course satisfaction in high school. Dissertation Abstracts International, 71(10A) (UMI No. 3466080).

Piccoli, G., Ahmad, R., \& Ives, B. (2001). Web-based virtual learning environments: a research framework and a preliminary assessment of effectiveness in basic IT skill training. MIS Quarterly, 25(4), 401-426.

Puzziferro, M. (2008). Online technologies self-efficacy and self-regulated learning as predictors of final grade and satisfaction in college-level online courses. American Journal of Distance Education, 22(2), 72-89.

Quintana, C., Zhang, M., \& Krajcik, J. (2005). Scaffolded software environments for supporting metacognitive aspects of online inquiry. Educational Psychologist, 40, 235-244.

Rovai, A. P., Ponton, M. K., Wighting, M. J., \& Baker, J. D. (2007). A comparative analysis of student motivation in traditional classroom and E-learning courses. International. Journal on E-Learning, 6(3), 413-432.

Schmader T, Johns M., \& Forbes C. (2008). An integrated process model of stereotype threat effects on performance. Psychological Review. 115, 336-356. 
Shapiro, A. (2000). The effect of interactive overviews on the development of conceptual structure in novices learning from hypermedia. Journal of Educational Multimedia \& Hypermedia, 9, 57-78.

Shea, P., \& Bidjerano, T. (2010). Learning presence: Towards a theory of self-efficacy, selfregulation, and the development of a communities of inquiry in online and blended learning environments. Computers \& Education, 55, 1721-1731.

Sher, A. (2009). Assessing the relationship of student-instructor and student-student interaction to student learning and satisfaction in web-based online learning environment. Journal of Interactive Online Learning, 8(2), 102-120.

Smith, D., \& Ayers, D. (2006). Culturally responsive pedagogy and online learning: implications for the globalized community college. Community College Journal of Research \& Practice, 30(5/6), 401-415.

Spencer, S. J., Steele, C. M., \& Quinn, D. M. (1999). Stereotype threat and women's math performance. Journal of Experimental Social Psychology, 35, 4-28.

Stokes, S. P. (2001). Satisfaction of college students with the digital learning environment. Do Learners’ temperaments make a difference. Internet and Higher Education, 4, 31-44.

Stone J. (2002). Battling doubt by avoiding practice: The effects of stereotype threat on selfhandicapping in White athletes. Personality and Social Psychology Bulletin 28, 16671678.

Steele C., Spencer S., \& Aronson J. (2002). Contending with group image: The psychology of stereotype and social identity threat. Advances Experimental Social Psychological. 34, $379-440$.

Steele, C. M. (1997). A threat in the air: How stereotypes shape intellectual identity and performance. American Psychologist, 52, 613-629.

Steele, C. M., \& Aronson, J. (1995). Stereotype threat and the intellectual test performance of African-Americans. Journal of Personality and Social Psychology, 69, 797-811.

Sun, P., Tsai, R. J., Finger, G., Chen, Y., \& Yeh, D. (2008). What drives a successful e-learning: An empirical investigation of the critical factors influencing learner satisfaction. Computers \& Education, 50 (4), 1183-1202.

Tashakkori, A., \& Teddlie, C. (2010). Handbook of mixed methods in social and behavioral research ( ${ }^{\text {nd }}$ ed.). Thousand Oaks, CA: Sage.

Timmis, S., \& Cook, J. (2004). Motivating students towards online learning: Institutional strategies and imperatives. The New Educational Benefits of ICT in Higher Education, 73-79. Retrieved October 26, 2015 from http://repub.eur.nl/res/pub/1233. 
Thurmond, V. A. (2003). Examination of interaction variables as predictors of students' satisfaction and willingness to enroll in future web-based courses while controlling for student characteristics. Retrieved February 6, 2015 from. http://www.bookpump.com/dps/pdf-b/ 1121814b.pdf

Thurmond, V. A., \& Wambach, K. (2004). Understanding interactions in distance education: A review of the literature. International Journal of Instructional Technology and Distance Learning, 1(1), 9-26.

Thurmond, V. A., Wambach, K., Connors, H. R., \& Frey, B. B. (2002). Evaluation of student satisfaction: Determining the impact of a Web-based environment by controlling for student characteristics. The American Journal of Distance Education, 16, 169-189.

Williams, M. (1996). Learner control and instructional technologies. In D. Jonassen (Ed.), Handbook of research on educational communications and technology (pp. 957-983). New York: Scholastic.

Wang, M. (2007). Designing online courses that effectively engage learners from diverse cultural backgrounds. British Journal of Educational Technology, 38(2), 294-311, Retrieved January 30, 2015, from ERIC database.

Wong, F., \& Trinidad, S. (2004). Using ICT in web-based distance learning to reduce the cultural distance. Journal of Interactive Online Learning, 3, 1-13.

Xu, D. \& Jaggars, S.S. (2011). Online and Hybrid Course Enrollment and Performance in Washington State Community and Technical Colleges (CCRC Working Paper No. 31). New York: Community College Research Center, Teachers College, Columbia University. Retrieved on January 3, 2015 from http://ccrc.tc.columbia.edu/Publication.asp?UID=872

Xu, D., \& Jaggars, S. S. (2013). The impact of online learning on students' course outcomes: Evidence from a large community and technical college system. Economics of Education Review, 37, 46-57.

Yen, H. J., \& Liu, S. (2009). Learner autonomy as a predictor of course success and final grades in community college online courses. Journal of Educational Computing Research, 41(3), 347-367.

Zimmerman, B. J. (1989). A social cognitive view of self-regulated academic learning. Journal of Educational Psychology, 81(3), 329-339. 